\title{
Kemikte Metastatik Nazofarenks Karsinomunun Aspirasyon Sitolojisi ve Hücre Bloğu Bulguları
}

\author{
Aspiration Cytology and Cell Block Findings of Metastatic Nasopharyngeal Carcinoma of Bone \\ Fatma Cavide SÖNMEZ1', Osman YILMAZ \\ Hacı Hasan ESEN ${ }^{2}$, Z. Esin ÇELIK ${ }^{3}$ \\ 'BezmiAlem Vakıf Üniversitesi, Tıp Fakültesi, Patoloji AD, İstanbul, \\ ${ }^{2}$ Necmettin Erbakan Üniversitesi, Meram Tıp Fakültesi, \\ ${ }^{3}$ Selçuk Üniversitesi, Tıp Fakültesi, Patoloji AD, Konya \\ ${ }^{4}$ Çorum Devlet Hastanesi, Patoloji Kliniği, Çorum
}

\section{ÖZET}

Nazofarenks karsinomu, nazofarenks epitelinden kaynaklanan ve tüm malign hastalıkların $\% 0.2^{\prime}$ sini oluşturan nadir bir tümördür. Uzak metastazları akciğerleri, iskelet sistemi ve karaciğeri içerebilir. Sitolojik inceleme, özellikle hücre bloğu bulguları metastatik nazofarenks karsinomu teşhisinde faydalıdır. Andiferansiye nazofarenks karsinomu olan ve İliak kemik metastazı bulunan olguyu sunduk ve metastatik odaktan hazırlanan aspirasyon sitolojisi ve hücre bloğunun bulgularını vurguladık.

Anahtar Kelimeler: Sitoloji, hücre bloğu, nazofarenks karsinomu, kemik, metastaz

\begin{abstract}
Nasopharyngeal carcinoma is a rare tumor arising from the epithelium of the nasopharynx and represents $0.2 \%$ of all malignant diseases. Distant metastases of this tumor may involve the lungs, skeleton, liver. Cytologic examination especially cell block findings is useful in the diagnosis of metastatic nasopharyngeal carcinoma. We report a case with undifferentiated nasopharyngeal carcinoma and distant metastasis to the iliac bone and emphasize the findings of aspiration cytology and cell block prepared from the metastatic focus.
\end{abstract}

Keywords: Cytology,cell block, nasopharyngeal carcinoma, bone, metastasis 


\section{GíRiş}

Nazofarenks karsinomu(NK) malign hastalıkların $\% 0.2$ 'sini oluşturur. Andiferansiye karsinom en sık görülen tiptir. Lenf nodu metastazı vakaların çoğunda bulunur (1). Uzak metastaz akciğerlere, iskelet sistemine, karaciğere ve bazen koroide olabilir (2).Kemik metastazı olan olgumuzda aspirasyon sitolojisi ve hücre bloğunda tespit ettiğimiz bulguları literatür verileri eşliğinde sunduk.

\section{OLGU SUNUMU}

Altmışyedi yaşında kadın hasta, sağ kalçasında ağrı ve şişlik nedeniyle başvurdu. Kalça MR incelemesinde sağ iliak kemikte, primer kemik tümörü ile uyumlu olduğu düşünülen $7.5 \mathrm{~cm}$ çapında kitle izlendi. Yapılan ilk biyopsinin yetersiz olması nedeniyle tanısı konulamayan hastaya iğne aspirasyon biyopsisi uygulandı. Hastanın sitoloji preparatlarının incelenmesinde oval, yuvarlak, veziküle nüveli, sitoplazmaları seçilemeyen atipik hücreler izlendi (Şekil I). Hücre bloğundan hazırlanan kesitlerde ise fibrin materyal içerisinde koheziv epitelyal tümör adaları şeklinde oval, yuvarlak, veziküle nüveli, belirgin eozinoflik nükleollü, sitoplazmaları seçilemeyen atipik hücreler görüldü (Şekil II). Bu hücreler İmmunhistokimyasal olarak Pansitokeratin ile (+) boyandı (Şekil III). Lenfoplazmositer hücreler ve nötrofilpolimorflardan oluşan iltihabi infiltrat da eşlik etmekteydi. Hastanın hikâyesinden 4 yıl önce nonkeratinize andiferansiye tip NK tanısı aldığı ve tedavi gördüğü öğrenildi. Karsinom infiltrasyonu olduğu belirtilerek malign sitolojik bulgular olarak raporlanan hastanın tanısı küretaj materyalinin histopatolojik incelemesi ile teyit edildi. Hastada NK dışında başka bir primer odak tespit edilmediği öğrenildi.

\section{TARTIŞMA}

NK 15-25 ve 60-69 yaşları arasında insidansı pik yapan (3) sık görülmeyen bir tümördür. (Keratinize) yassı epitel hücreli karsinom ile diferansiye ve andiferansiye nonkeratinize karsinom olmak üzere sınıflandırılır. Lenf nodu metastazı sık olup (1) uygulanan iğne aspirasyon biyopsisi (IAB) tanısal özellikler taşır (4). Bu özellikleri tanımlamak için çeşitli çalışmalar yapılmıştır. Me-

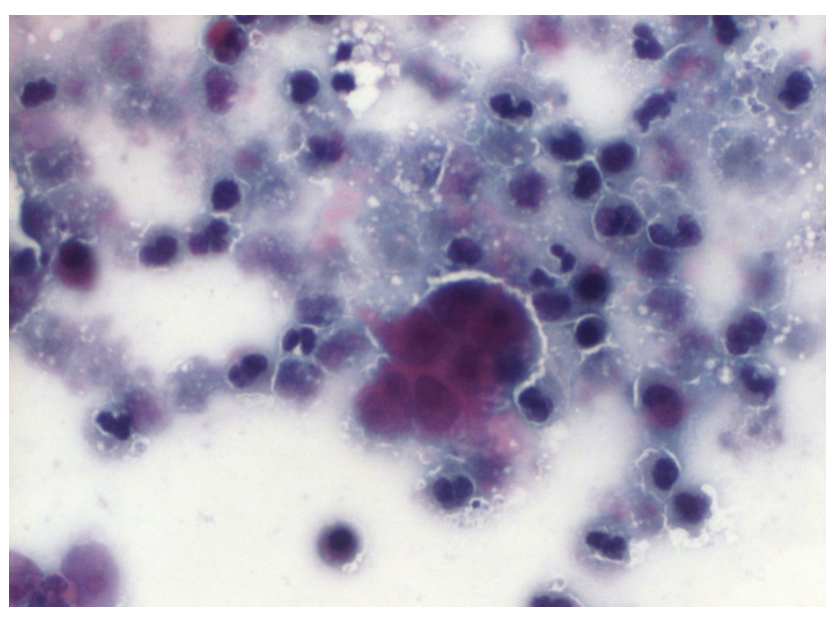

Şekil I: HEx100-Aspirasyon sitolojisi bulguları: nekrotik zeminde, nükleolleri belirgin, pleomorfik nüveli, sitoplazma sınıları belirsiz tümör hücre kümesi ve eşlik eden iltihabi infiltrat.

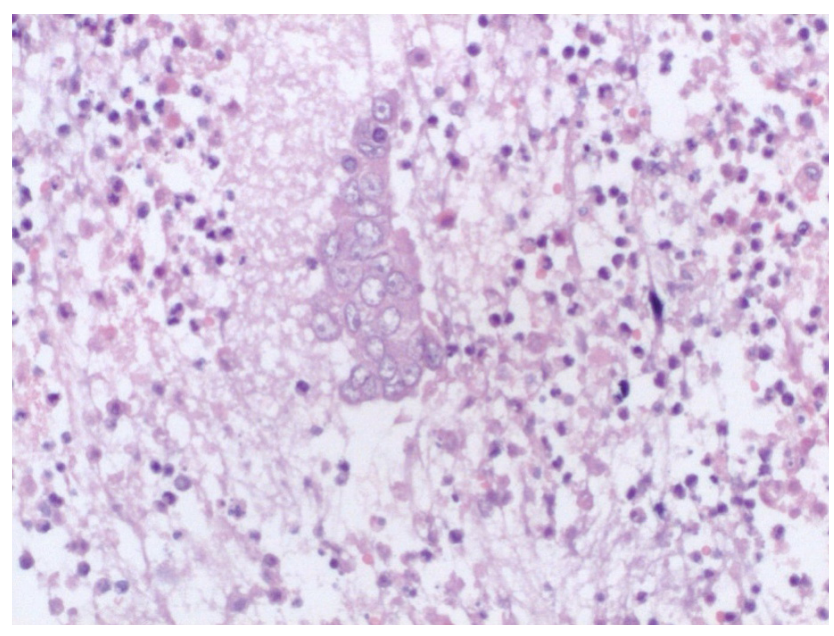

Şekil II: HEx100-Hücre bloğu bulguları: inflame, nekrobiyotik zeminde koheziv epitelyal tümör adası.

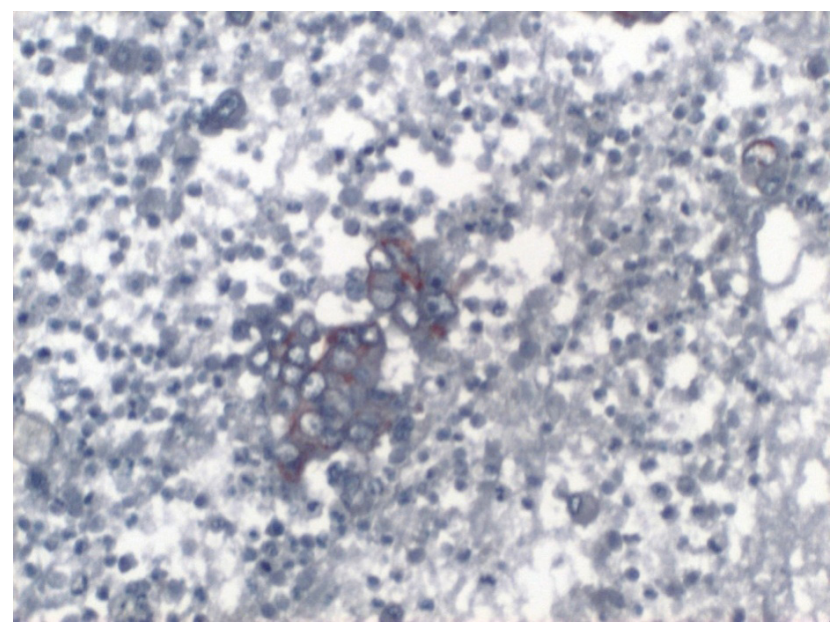

Şekil III: Hücre bloğundaki tümör hücrelerinin immunhistokimyasal Pansitokeratin ekspresyonu.

tastatik NK'lı hastalardan alınan 54 adet IAB incelendiğinde lenfoid komponent de içeren, tek tek hücreler halinde veya gruplar oluşturmuş, büyük, anaplastik, çıplak çekirdekli hücrelerin andiferansiye karsinomu kuvvetle düşündürdü- 
ğü sonucu çıkarılmıştır (5). Başka bir çalışmada tümör hücre grupları ile ilişkili plazma hücrelerinin nazofarengeal orijin için iyi bir gösterge olduğu görülmüştür (6). 15 vakalık bir çalışmada ise metastatik lenf nodundan alınan İA'de selüler dejenerasyon ve çıplak çekirdekli tümör hücreleri tüm vakalarda görülmüş, orta-belirgin pleomorfizm gösteren, veziküler kromatinli, sitoplazmik sınırları seçilemeyen, dar sitoplazmalı hücreler izlenmiştir (7). Sonuç olarak hem primer hem de metastatik NK olgularında aspirasyon sitolojisi tanıda değerlidir. Hücre bloğu ayırıcı tanı için daha rahat immunhistokimyasal çalışma ve daha detaylı patern değerlendirme olanağı sunar.

\section{KAYNAKLAR}

1-Weber AL, al-Arayedh $S$, Rashid A. Nasopharynx: Clinical, pathologic, and radiologic assessment. Neuroimaging Clin $\mathrm{N}$ Am 2003;13(3):465-83.

2-Lee DK. Distant metastases to the hallux in nasopharyngeal carcinoma J Am Podiatr Med Assoc 2008;98(3):239-41.

3-Juan Rosai. Rosai and Ackerman's surgical pathology, 9ncu baskı: Mosby, 2004:311-315.

4-Chan MK, Huang DP. The value of cytologic examination for nasopharyngeal carcinoma. Ear Nose Throat J 1990;69(4):268-71.

5-Viguer JM, Jiménez-Heffernan JA, LópezFerrer $P$, Banaclocha $M$, Vicandi B. Fineneedle aspiration cytology of metastatic nasopharyngeal carcinoma. Diagn Cytopathol 2005;32(4):233-7.

6-Kollur SM, El Hag IA. Fine-needle aspiration cytology of metastatic nasopharyngeal carcinoma in cervical lymph nodes: comparison with metastatic squamous-cell carcinoma, and Hodgkin's and non-Hodgkin's lymphoma Diagn Cytopathol $2003 ; 28(1): 18-22$.

7-Mohanty SK, Dey P, Ghoshal S, Saikia UN. Cytologic features of metastatic nasopharyngeal carcinoma. Diagn Cytopathol 2002;27(6):340-2. 